SCATTER 2 



\section{Scatter 2}

\section{Politics in Deconstruction}

\section{Geoffrey Bennington}

F O R D H A U N I VERS ITY PRES S

New York 202 I 
Copyright (C) 202 I Fordham University Press

All rights reserved. No part of this publication may be reproduced, stored in a retrieval system, or transmitted in any form or by any means-electronic, mechanical, photocopy, recording, or any other-except for brief quotations in printed reviews, without the prior permission of the publisher.

Fordham University Press has no responsibility for the persistence or accuracy of URLs for external or third-party Internet websites referred to in this publication and does not guarantee that any content on such websites is, or will remain, accurate or appropriate.

Fordham University Press also publishes its books in a variety of electronic formats. Some content that appears in print may not be available in electronic books.

Visit us online at www.fordhampress.com.

Library of Congress Cataloging-in-Publication Data

Names: Bennington, Geoffrey, author.

Title: Scatter 2 : politics in deconstruction / Geoffrey Bennington.

Other titles: Scatter two

Description: First edition. I New York : Fordham University Press, 202 I. I

Includes bibliographical references and index.

Identifiers: LCCN 202004I477 | ISBN 9780823289929 (hardback) I ISBN

9780823289936 (paperback) I ISBN 9780823289936 (epub)

Subjects: LCSH: Political science-Philosophy-History. I

Democracy_Philosophy. I Sovereignty_Philosophy.

Classification: LCC JA83 .B446 202 I I DDC $320.01-d c 23$

$\mathrm{LC}$ record available at https://lccn.loc.gov/202004I 477

Printed in the United States of America

23222 I 5432 I

First edition 
for Elissa, again and always 
